\title{
Cultural Influence on Educational Leadership in Albania
}

\author{
Magdalini Vampa
}

\begin{abstract}
Leadership theories, the "Great Man" theory, charismatic theory of leadership, contingency theories, the theory of attributes, etc. help us understand and explain the leadership process and the role of leader, but none of them treats the complexity of human interaction in the leadership phenomena. Implicit theory began to draw some conclusions in early 90 s, by defining leadership from the perspective of subordinates when leadership attitude is manifested, and more specifically how cultural groups "prepare" and respond to leadership. The main aim of this paper is to describe some aspects of management styles of school organizations in Albanian society, by taking in consideration the cultural influence on management effectiveness. Implicit theory of leadership developed by Lord \& Maher, as well as the results of the prestigious GLOBE project, guided the elaboration of this work. Cultural dimensions used by researchers in GLOBE project, are reused in data collection of this study, but in a narrow context: only for educational organizations, in a Region in Albania. Concerning literature, we have tried to explain how school management practices are built upon an epistemological relationship and empirical life experience, which is qualitatively distinct from north to south and from east to west.
\end{abstract}

Keywords: leadership, school management, cultural dimension, leader profile, etc.

\section{Introduction}

The challenge of globalization requires that cultural organizations and schools should be identified by the right leaders, who know how to recognize, understand, respect and manage the cultural differences between societies and countries.

Referring to the situation of countries like Albania, the need to achieve global standards in education, and the recognition of cultural influences in management, is directly related to the implementation of the reform models that derive from these different cultures.

This paper is focused on leadership understanding from the perspective of culture, and is based on implicit theory of Lord \& Maher, and in particular, on the conclusions of the GLOBE Project, run by the House, Hanges, Javidan, Dorfman and Gupta in 2004.

The results of this study were based on data collected in 62 different countries with the participation of 17, 000 managers of 980 cultural organizations. The involvement of Eastern European countries in this project has facilitated the monitoring and collection of preliminary data on school environments in Albania.

Actually, the data and analysis realized in relation to the school leadership in Albania, was conducted through several measuring instruments as surveys, structured interviews, semi-structured interviews, on a sample of 300 subjects, 200 of whom managers of educational institutions in Korca Region and the rest, teachers and employees of educational organizations and institutions. Korca Region is one of 12 regions of the country, where education levels and institutions are from preschools to higher education institutions, both public and private. ) The field study was conducted in a two-year period, 2012-2013. Besides, surveys and structured interviews, a significant part of the interviewees were ready to participate in unstructured interviews, by providing broader information. Some conclusions of this study are presented in the final part of this paper.

The conclusions drawn in this paper explain some problems encountered during the reform processes, as well as provide modest recommendations to improve understanding cultural interaction in the management process.

Structure of the paper 
At the beginning of this paper it is defined the concept of leadership, ethnocentrism and prejudice, trying to clarify the understanding of these concepts from the perspective of this study. Then, there are described the cultural dimensions and findings of the Globe Project, focusing on the Eastern Europe culture, and on the other part we will bring the results of this study in Albania.

\section{Definition of management and culture. Concepts related to them.}

Leadership is a process whereby an individual influences a group of individuals to achieve a common goal. Northouse, $\mathrm{R}$, 2010 , p. 3) In this definition, it is important the treatment of leadership as a process, which implies the leader influence on the group performance and vice versa, the group influence on leadership as a linear and interactive event.

Groups are contexts where leadership appears, and orients the energies and potentials of group members towards achievement of common goals. The researchers believe that although the leaders and their followers are related to each other, leaders initiate relationships, establish communication lines and try to keep a sustainable cooperation.

Culture is a set of learned beliefs, values, rules, norms, symbols and traditions that are common to a group of people. It is exactly these qualities that make a group unique and special. Culture is dynamic and it is transmitted to others.

Two concepts related to culture and management are: ethnocentrism and prejudice.

Ethnocentrism is the tendency of individuals to give priority to their own beliefs, values and attitudes over the others. Ethnocentrism means that individuals of a culture judge other groups in a subjective or critical way.

Ethnocentrism could become a serious obstacle to the effectiveness of leadership because it doesn't allow managers to understand or fully respect others views, e. g. a leader who strongly believes in respect to authority, has difficulties in treating and respecting his followers when they challenge their leader and his authority as part of their culture.

Prejudice is an attitude, a belief or an emotion formed without enough thought and knowledge and based on unfair and unreasonable opinion or feeling. Prejudice includes inflexible conclusions that cannot accept the alteration or even the total change.

Leader faces continuous challenge to confront their prejudices toward subordinates and subordinate's prejudices against management and him as a leader.

\section{Cultural dimensions and cultural groups according to the project Globe}

Various scholars in the past 30 years have tried to characterize the term culture from the leadership point of view.

Hall in his book Beyond Culture (1976) focuses his research in two features: individual and collectivist culture.

Trompenaars (1994) in his observation of 15, 000 individuals in 47 countries classifies two important dimensions of culture: equality versus hierarchy and the person as a human being in front of his duty and responsibility.

Hofstede (2001), based on the analysis of questionnaires conducted on 100, 000 respondents in 50 countries, identifies five dimensions that differ in every culture: power distance, uncertainty avoidance, individualism-collectivism, masculinity femininity, long-term and short-term orientation.

The study of House, Hanges, Javidan, Dorfman and Gupta (2004) provide one of the most referred studies and reliable results concerning the specific field of culture and leadership; it is also called the GLOBE study of 62 societies, with the observation and interviews of 17.000 managers of 980 organizations.

The researchers of this project identified nine dimensions of culture from the perspective of management: uncertainty avoidance, power distance, Institutional Collectivism, In-Group Collectivism, gender egalitarianism, assertiveness, future orientation, performance orientation, humane orientation.

The GLOBE research program investigated cultural approaches to leadership in 62 countries related to their cultural dimensions. The sample of 62 countries was divided in 10 groups based on common language, geography, religion and historical data. They are: Anglo, Germanic, Latin Europe, Central Africa, Eastern Europe, Middle East, Confucian Asia, South Asia, Latin America, and Nordic Europe. 
Table 1. Cultural groups classified according to their cultural dimensions

\begin{tabular}{|l|l|l|}
\hline Cultural dimension & The highest scores of cultural groups & The lowest scores of cultural groups \\
\hline $\begin{array}{l}\text { Orientation towards being assertive, } \\
\text { determined and aggressive. }\end{array}$ & $\begin{array}{l}\text { Eastern Europe } \\
\text { Assertiveness }\end{array}$ & Nordic Countries \\
\hline Future Orientation & $\begin{array}{l}\text { Germanic Europe ( } \\
\text { Nordic Countries }\end{array}$ & $\begin{array}{l}\text { Eastern Europe } \\
\text { Latin America } \\
\text { Middle East }\end{array}$ \\
\hline Gender Egalitarianism & Eastern Europe \\
& Nordic Countries & Middle East \\
\hline Humane Orientation & $\begin{array}{l}\text { South Asia } \\
\text { Central Africa }\end{array}$ & $\begin{array}{l}\text { Germanic Europe ( } \\
\text { Latin Europe }\end{array}$ \\
\hline In-Group Collectivism & $\begin{array}{l}\text { Confucian Asia, } \\
\text { Eastern Europe, } \\
\text { Latin America, } \\
\text { Middle East, } \\
\text { South Asia }\end{array}$ & $\begin{array}{l}\text { Anglo } \\
\text { Nermanic Europe }\end{array}$ \\
\hline Institutional Collectivism & $\begin{array}{l}\text { Nordic Countries } \\
\text { Confucian Asia }\end{array}$ \\
\hline Performance Orientation & $\begin{array}{l}\text { Anglo } \\
\text { Confucian Asia } \\
\text { Germanic Europe }\end{array}$ & $\begin{array}{l}\text { Germanic Europe } \\
\text { Latin America, } \\
\text { Latin Europe }\end{array}$ \\
\hline Power Distance & None & $\begin{array}{l}\text { Eastern Europe } \\
\text { Latin America }\end{array}$ \\
\hline Uncertainty Avoidance & Germanic Europe & Nordic Countries \\
& Nordic Countries & $\begin{array}{l}\text { Eastern Europe } \\
\text { Latin America } \\
\text { Middle East }\end{array}$ \\
\hline
\end{tabular}

Source: This table is taken from Leadership, Theory and practice Northouse 2010, which is adopted by the author with the permission of GLOBE project, p. 344.

Based on the GLOBE project, House \& Javidan 2004, Hofstede 1991, Trompenaars \& Hampdin-Turner 1997, we were able to identify six global management features:

Charismatic type is a visionary leadership, inspirational, reliable, determined, and performance-oriented.

Team-oriented is characterized by integration, team collaboration, diplomacy, and aims to create the group by making clear the common intention.

Inclusive leadership, participative in decision making process; encourages involvement and engagement in decision making process and is characterized by non-autocratic behaviour.

Human orientated displays support, consideration, compassion and generosity, is characterized by modesty and compassion for others.

Autonomous; is characterized by an independent and individualistic approach to leadership.

Self-protective; is reflected in the behaviour of leader, focusing on the safety and security of the individual and the group, egocentric, emphasizes his status, capable of inducing conflict when necessary, but at the same time being conscious of his reputation, etc.

Ten cultural groups, mentioned above, are analysed after data collection by defining respective profiles of the leader and leadership.

\section{Eastern European Leadership Profile}

An ideal leadership, especially in educational organizations, in Eastern European countries, would be an individual who first and foremost would be independent while maintaining strong interest in protecting his position as a leader. Preferably, 
he would be charismatic, value-based leadership, team-oriented and humane-oriented, but much less interested in the involvement of his followers and staff in the decision-making process.

In summary: this culture clearly describes his leader as autonomous, who takes the decisions independently, presents some degree of being inspiring, guides the teamwork and to some extents pays attention to human needs.

In an attempt to use this important information about the situation in Albania, this paper has brought just a few cultural profiles of the region as well as those cultures which have served as models in the long process of educational reform in our country.

\section{Anglo-American leadership profile:}

The Anglo-American leadership profile emphasizes that the leader, first of all, should be charismatic, a value based leadership, who allows and supports the participation of his followers in the decision-making process, is sensitive toward his staff and others. This culture requires leaders who are extremely motivated and visionary, not autocratic and take in consideration others opinions. These countries prefer a moderate level of work in group and respect toward an independent attitude. Less important feature of the leader's image in this cultural group is the protective role. They believe that it is ineffective if the leader tries to establish his status, or attempts to be at the centre of every situation.

\section{Germanic Europe leadership profile}

The ideal leadership in Germanic Europe should be unique, visionary, autonomous, charismatic, human oriented as well as team oriented, but not with a self-determined status or who takes care of protecting the dignity of his staff.

\section{Nordic Europe leadership profile}

The ideal example of the leadership in Nordic Europe is a leader with clear and inclusive vision of decision-making process, and with some characteristics of independence and diplomacy. In this culture, it is less important the humanity and selfdetermined status of the leader, in other words, Nordic countries prefer leaders who inspire and involve their staff in decision making process, and do not expect them to be concerned about their status or others attitudes.

\section{Summary:}

Scholars and supporters of the theory of leadership and culture summarize and elaborate a set of characteristics and capabilities that universally define the negative and positive qualities and attitudes of the leadership. Specifically, the most distinguished personality of a leader is that of a person of high integrity, charismatic, and with interpersonal skills. An ineffective leader is someone who appears asocial, ruthless, egocentric and autocratic.

\section{Some characteristics of leadership in Albanian culture}

The implicit theory of leadership is still developing and elaborating its ideas, because of its philosophy which stands and takes care of the perception of leadership and management from the perspective of others, and does not take into consideration the leader's behaviour, situations and different contexts.

The presented models and efforts for the democratization of the schools in Albania, in order to achieve European standards, always refer to educational systems of western developed countries. To achieve the purpose and a successful implementation of these models and changes, we should be conscious and clear about the impact of culture on leadership, and how the culture of our country differs in several dimensions to the culture of these countries.

The knowledge and the study of these characteristics will bring better opportunities for communication and change of the targeted program as well as its adoption in a natural way.

The received information about some dimensions of culture according to the above-mentioned definitions will be presented below, by treating (1) the aspects of management process, (2) management of changes and (3) evaluation of teachers by the leader.

The GLOBE project research concluded that Eastern European countries present a group-oriented culture and evaluate the importance of the relationship between members and not the effectiveness or performance of the individual. In these countries, education is mostly marked as a tool to adapt students and staff with community expectations. 
Leaders in educational organizations in Albania are more focused in increasing the harmony of teaching staff and then on student's achievements according to the standards required by the Ministry of Education, and it is of primary importance too. Leaders in Albanian schools tend to establish the relationship with the staff, before taking the position as leaders. The first request or advice of an Albanian leader to a new employee is: try to create a nice atmosphere, a good communication with the staff and. ... then we can talk about the duties and performance.

In European countries like Germany, France or the Netherlands, school leaders and managers are more interested in meeting the individual needs of students and teaching staff.

In Albania, where the power of individual depends on external factors and is closely related to politics, the leader is headed toward an autocratic behaviour. Interviewed people agree that the leader's status and reputation can be attributed to his age, position, family or relation to the central government. The same views are shared in some of Confucian Asia countries, while in western countries such as Anglo countries, Germanic European and Nordic countries; the respect toward the leader is attributed to his competence and management skills.

In Albanian culture, facing the conflict is very different compared to the same situation in Anglo-American and Germanic countries. Albanian staff tends to avoid open confrontation and persistence against the leaders. Thus, interviewed people claimed obvious deviations of the disapproval of leader's opinion, even when staff interests were affected.

Leaders themselves try to precede conflicting situations with an authoritarian style in decision making process, appearing self-protective. In other countries, as we mentioned above, decisions and policies are faced by all the staff, and conflicts are allowed to develop up to negotiations, and often leaders allow the status quo but not an authoritative decision-making process.

Change, reform and access to "Western" ideas, are challenges that stand before the Albanian education system for over a century now. Reforms based on western models aim a curricular reform as well as a contemporary pedagogical approach. The example below will reveal the importance of the role of education leaders, particularly in schools where changes will be implemented, but the implication of cultures make it difficult (the culture of model's origin and the culture where it will be implemented).

Specifically, in unstructured interviews about the student-centred teaching model, $90 \%$ of interviewed teachers expressed uncertainty in understanding it. Continuous requirements for training, application or even pilot projects regarding the benefits of using this model, has had an inefficient impact because of the lack of clear philosophy transition. School leaders, accompanied by their autocratic and non-participative character couldn't initiate this change. Leaders and teachers understood it as a new technique of putting the students chair in a circle, not in classical form where the teacher stands in front of the class.

The same situation appears in Hong Kong (Walker \&Dimmock 2002), where education reform projects failed after many efforts. It was intended to implement during ' 95 -' 96 , but failed for almost the same reasons: lack of culture recognition, the philosophy of that model and the different pedagogical approach. And at the same time in Thailand, it is the voluntary choice of some school leaders to apply this model.

They were trained, worked hard, and managed to integrate the student-centred teaching model in three pilot schools. This became possible after leaders themselves avoided autocracy and non-collaborative attitude (part of Confucian national culture) to their staff and students when explained and oriented them towards the application of this model.

In their (3) teacher evaluation models, Western countries generally try to focus on individual performance rather than to the relationship with their colleagues or the ability to adopt with group or school environment.

When school leaders were asked about the evaluation of their staff, they were focused on a common position: their concern and interest was related to how teachers adapt to the staff, their communication skills, how they support and were supported by their colleagues and then about their professional ability. So, the relationship is appreciated more than duty and efficiency. In general, the leader instructions are related to the motivation of individuals to adopt with the staff, to control their own emotions, to avoid competition and conflict. In regard to these conclusions we can quote Westwood \& Kirkbride (1998) after a research study in Eastern European countries and Asia: "Harmony (in these countries) is a primary moral norm, is the foundation upon which grows the "collectivism". 
It is claimed that teachers in Albania have a high threshold of tolerance toward judgment and subjective assessments, as long as they believe in their leader. They choose to be evaluated for their efforts and not for their achievements. The comparison to Anglo American countries clearly shows the opposite position. To measure their achievements, teachers in Western schools require precise and more sophisticated instruments based on standards and objectivity. Achievement is related only to the individual.

If Nordic countries appreciate the avoidance of uncertainty as a leadership value by implying the need for strict rules, specific and precise objectives, and clear destination, for Albanians this is a dimension that isn't measured, and doesn't comfort individuals belonging to this group-oriented culture. GLOBE)

\section{Conclusions:}

Globalization is creating a need for leaders who enhance understanding of cultural differences and competences in intercultural communication as well as in practice.

Hofstede quoted by Walker\&Dimmnock (2002, p. 190), states: Institutions do differ. By way do they differ? In attempting to understand institutional differences, one needs history, and in understanding history one needs culture. Culture is at the root of institutional arrangement, and even if the sociologist does not dare to venture historical/cultural explanations, cultural differences appear as a consequence of institutional differences...thinking is affected by the kind of family they grew up in, the kind of school they went to, the kind of authorities and legal system they are accustomed to. The causality between institutions and culture is circular: they cannot be separated.

\section{References:}

[1] Hall, E. T. 1976). Beyond Culture. New York: Daubleday. Only reading (http://www. amazon. com/BeyondCulture-Edward-T-Hall/dp/0385124740

[2] Hofstede, G. 2001) Culture's consequences, Comparing values, behaviors, institutions and organizations across nations, Second edition, Sage

[3] House, Hanges, Javidan, Dorfma and Gupta (2004). Culture, Leadership, and Organizations: The GLOBE Study of 62 Societies, Thousand Oaks, CA: Sage, p. 669-722

[4] Northouse, R. , (2010). Leadership Theory and Practice, Sage Publications, Thousand Oak, CA.

[5] Trompenaars, A. 1994). Riding the waves of culture: Understanding diversity in global business. New York: Irvin

[6] Walker, A. , \& Dimmock, C. , (2002) Moving School Leadership Beyond its Narrow Boundaries: Developing a Cross-Cultural Approach. Second International Handbook of Research on Educational Leadership and Administration. Dordrecht, The Netherlands: Kluwer Academic Press. p. 167-202.

[7] Westwood, R. I. , \& Kirkbride, P. S. 1998) International strategies of corporate culture change: Emulation, consumption and hybridity. Journal of Organizational Change Management, Volume 11, nr. 6, pg. 554-577. 